\title{
PENGARUH INTELLECTUAL CAPITAL PERFORMANCE TERHADAP INTENSITAS PELAPORAN MODAL INTELEKTUAL
}

\author{
Riska Harisnawati, Ihyaul Ulum, Daniel Syam \\ Prodi Akuntansi FEB Universitas Muhammadiyah Malang \\ Jl. Raya Tlogomas No.246 Malang \\ Email :riskaharisnawati9@gmail.com
}

\begin{abstract}
The annual report as one of disclosure information made by a company. Purpose of this study to analyze the effect of intellectual capital reporting performance to the intensity of intellectual capital. Sample of this study are that the Islamic banking registered at Bank Indonesia in period 2011 to 2015. Samples were selected using purposive sampling method and obtained 24 Islamic banking which is 9 for Islamic Banks and 15 for Islamic business unit. The analysis tool used is WarpPLS 3.0 with assessing inner and outer models prior models to test data analysis is feasible or not. Results of this study indicate that intellectual capital performance significant positive effect on the intensity of intellectual capital reporting.
\end{abstract}

Keywords: Intellectual Capital Performance, Intellectual Capital

\section{PENDAHULUAN}

Pentingnya pengungkapan (disclosure) suatu informasi dalam pelaporan keuangan dapat memberikan manfaat bagi para pengguna informasi agar terjalin komunikasi yang baik dengan pihak manajemen. Sebagaimana yang dijelaskan oleh Healy dan Palepu (2001), yang menyatakan perlunya pengungkapan keuangan sebagai sarana komunikasi yang lebih baik antara pengguna informasi dan pihak manajemen dengan membangun strategi-strategi disclosure guna mengurangi adanya asimetri informasi yang timbul dalam hubungan kedua pihak.

Pengungkapan terdiri dari dua jenis yaitu pengungkapan bersifat wajib (mandatory disclosure) dan pengungkapan bersifat sukarela (voluntary disclosure). Pengungkapan wajib (mandatory disclosure) merupakan pengungkapan yang diatur oleh Badan Pengawas Pasar Modal sedangkan pengungkapan sukarela (voluntary disclosure) merupakan pengungkapan yang diberikan oleh perusahaan sebagai tambahan dari pengungkapan wajib (Wardani, 2012).

Pengungkapan modal intelektual (ICD) merupakan salah satu yang menjadi perhatian para akademisi maupun praktisi dalam menentukan nilai perusahaan. Meskipun demikian, pengungkapan modal intelektual ini belum banyak dilakukan oleh semua perusahaan, hal itu dikarenakan tidak ada kesadaran pihak manajemen dalam mengungkapkan modal intelektual yang dimilikinya. Guthrie dan Petty (2000) menjelaskan adanya fakta bahwa saat ini disclosure IC memberikan kemanfaatan yang lebih besar dibandingkan di masa lalu. Kemanfaatan tersebutlah yang dapat mendorong perusahaan untuk melakukan penggungkapan modal intelektual yang dimilikinya dalam menentukan nilai perusahaan.

Ulum et al. (2012) menggunakan 38 perusahaan dan hasil penelitiannya menunjukkan bahwa karakteristik perusahaan berpengaruh signifikan terhadap praktek pengungkapan modal intelektual dalam laporan tahunan perusahaan.

Hasil penelitian Ulum et al. (2012) bertentangan dengan yang diteliti oleh Will-

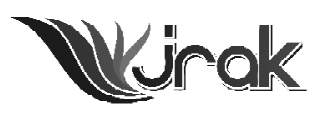

Jurnal Reviu Akuntansi dan Keuangan ISSN: 2088-0685 Vol. 7 No. 1, April 2017 Pp 941-950 


\section{Pengaruh Intellectual Capital...}

iams (2001) meneliti dengan menggunakan 30 perusahaan publik di Inggris yang masuk dalam kelompok FTSE 100 dan dengan menggunakan teknik analisis regresi. Hasil penelitian nya menunjukkan bahwa ICP berhubungan negatif terhadap praktik pengungkapan IC dalam laporan tahunan perusahaan. Penelitian ini didukung dengan hasil penelitian Ulum (2012) dengan menggunakan 75 perusahaan publik di Afrika Selatan dan menggunakan teknis analisis yang sama hasil penelitiannya juga menunjukkan bahwa ICP berhubungan negatif terhadap ICD.

Penelitian ini akan menguji pengaruh intellectual capital performance (ICP) terhadap intensitas pelaporan modal intelektual. Objek yang digunakan dalam penelitian ini menggunakan perbankan syariah, karena dalam pengungkapan laporan keuangan nya berbeda dengan bank konvensional. Penelitian ini menggunakan formulasi ICD untuk Indonesia yang dikembangkan oleh Ulum (2015b) yaitu ICD-in (Intellectual Capital Disclosure Indonesia). ICD-in merupakan modifikasi yang dibangun oleh Guthrie et al (1999), yang merupakan pengembangan dari definisi IC yang ditawarkan oleh Sveby (1997), yang juga digunakan oleh Brennan (2001).

\section{PENGEMBANGAN HIPOTESIS}

Wernerfelt (1984) menjelaskan bahwa menurut pandangan Resource Based Theory perusahaan memperoleh keunggulan kompetitif dan kinerja keuangan yang baik dengan cara memiliki, menguasai, dan memanfaatkan aset-aset strategis yang penting, termasuk aset berwujud (tangible) maupun aset tidak berwujud (intangible). Resource Based Theory merupakan sumber daya berharga, langka, tidak dapat ditiru dan tidak ada sumber daya pengganti yang dimiliki perusahaan. Teori RBT ini mengharuskan manajemen untuk melihat kedalam perusahaan untuk menemukan sumber - sumber keunggulan kompetitif melalui sumber daya yang mereka miliki. Keungulan kompetitif yang dimiliki perusahaan adalah suatu keuntungan bahwa perusahaan akan dapat bersaing dan dapat meningkatkan nilai perusahaannya. Selain itu juga perusahaan dapat meningkatkan margin yang diperoleh dan juga dapat mempertahankan pelanggan dari kompetitor.

Penelitian yang dilakukan oleh Williams (2001) hasilnya menunjukkan bahwa ICP berhubungan negatif terhadap praktik pengungkapan IC dalam laporan tahunan perusahaan. Hasil yang sama juga ditemukan oleh Ulum (2015c) yang menyatakan bahwa ICP tidak berpengaruh terhadap pengungkapan modal intelektual didalam laporan keuangan perusahaan.

Penelitian tersebut bertentangan dengan teori RBT maupun teori stakeholder yang menjelaskan bahwa seberapa penting pelaporan modal intelektual didalam laporan keuangan perusahaan. Menurut teori stakeholder, manajemen organisasi diharapkan untuk memberikan informasi mengenai aktivitas-aktivitas yang dilakukannya kepada stakeholder. Sementara dalam perspektif RBT, IC adalah sumber daya yang dapat membantu perusahaan mencapai keunggulan bersaing, sehingga dengan demikian harusnya ICP yang tinggi dapat mendorong para manajemen organisasi dalam mengungkapkan informasi IC yang dimilikinya. hal tersebut merupakan informasi yang baik bagi perusahaan, dengan itu perusahaan dapat memperluas pelaporan modal intelektual yang dimiliki nya. Karena dengan memperluas pelaporannya dapat meningkatkan nilai perusahaan dalam mencapai keunggulan bersaing.

Dengan demikian, maka hipotesis yang diajukan dalam penelitian ini adalah:

$\mathrm{H}_{1}$ : Intellectual Capital Performance berpengaruh positif terhadap intensitas pelaporan modal intelektual. 


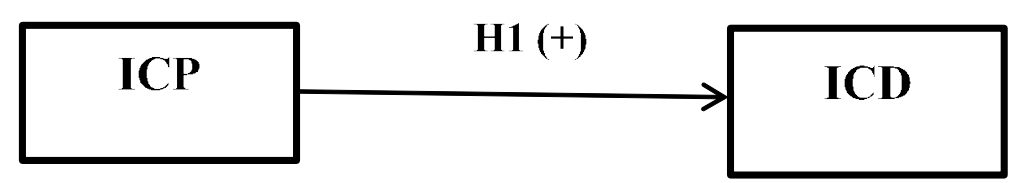

\section{METODE}

Pengambilan sampel dilakukan dengan menggunakan metode purposive sampling (Ulum dan Juanda, 2016). Adapun kriteria yang menjadi dasar pemilihan sampel berdasarkan tujuan penelitian adalah :

1. Bank Umum Syariah dan Unit Usaha Syariah yang terdaftar di Bank Indonesia dari tahun 2011-2015.

2. Bank Umum Syariah dan Unit Usaha Syariah yang mempublikasikan laporan tahunan dan laporan keuangan dari tahun 2011-2015.

3. Bank Umum Syariah dan Unit Usaha Syariah yang tidak mengalami rugi dari tahun 2011 - 2015.

Variabel dependen dalam penelitian ini adalah pengungkapan modal intelektual (intellectual capital disclosure). ICD adalah jumlah pengungkapan informasi tentang IC yang disajikan dalam laporan tahunan perusahaan (Ulum 2015). Komponen ICD yang digunakan dalam penelitian ini yaitu meliputi Human Capital, Struktural Capital, Relational Capital. Pengukuran ICD menggunakan Framework 36, pengungkapan informasi IC dalam laporan tahunan diberi bobot sesuai dengan proyeksinya.

Framework untuk pengungkapan IC dalam penelitian ini menggunakan 36 item disebut juga dengan ICD-In (Intellectual Capital Disclosure Indonesia) yang dikembangkan oleh Ulum (2015a). Berikut ini adalah framework ICD-In :

1) Kategori Human Capital

1. Jumlah karyawan

5. Kompetensi karyawan

2. Level pendidikan

6. Pendidikan \& pelatihan

3. Kualifikasi karyawan

7. Jenis pelatihan terkait

4. Pengetahuan karyawan

8. Turnover karyawan

2) Structural Capital

9. Visi misi

10. Kode etik

11. Hak paten

12. Hak cipta

13. Trademarks

14. Filosofi manajemen

15. Budaya organisasi

16. Proses manajemen
17. Sistem informasi

18. Sistem jaringan

19. Corporate governance

20. Sistem pelaporan pelanggaran

21. Analisis kinerja keuangan komprehensif

22. Kemampuan membayar hutang

23. Struktur permodalan

\section{3) Relational Capital}
24. Brand
25. Pelanggan
26. Loyalitas pelanggan
27. Nama perusahaan
28. Jaringan distribusi
29. Kolaborasi bisnis
30. Perjanjian lisensi

31. Kontrak - kontrak yang menguntungkan

32. Perjanjian franchise

33. Penghargaan

34. Sertifikasi

35. Strategi pemasaran

36. Pangsa pasar
Gambar 1.

Model Empiris

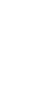


Pengaruh Intellectual Capital...

944
Proses identifikasi ICD dilakukan dengan 4 cara sistem kode numerik (fourway numerical coding system) yang dikembangkan oleh Guthrie et al. (1999), yaitu: $0 \quad=$ item tidak diungkapkan dalam laporan tahunan

1 = item diungkapkan dalam bentuk narasi

2 = item diungkapkan dalam bentuk narasi

3 = item diungkapan dengan nilai moneter

Selanjutnya pengungkapan Intellectual Capital dibuat skor index untuk memunculkan satu angka bagi masing-masing perusahaan dengan cara menjumlahkan skor pengungkapan dibagi dengan skor kumulatif:

$$
\text { ICD }=\frac{\text { TOTAL SKOR PENGUNGKA PAN }}{\text { TOTAL ITEM ICD }- \text { IN }}
$$

Sedangkan variabel independen dalam penelitian ini adalah intellectual capital performance (ICP). ICP adalah kinerja modal intelektual yang menggambarkan kemampuan perusahaan dalam mengelola dan memaksimalkan IC yang dimilikinya. Pengukuran kinerja IC yang digunakan dalam penelitian ini adalah Modified VAIC (MVAIC).

Formulasi MVAIC dan tahapan yang dikembangkan oleh Ulum et al. (2014) sebagai berikut:

Langkah pertama: Menghitung Value Added (VA)

- VA = OUT - IN

Langkah kedua: Menghitung IC Efficiency (ICE)

- $\mathrm{ICE} \quad=\mathrm{HCE}+\mathrm{SCE}+\mathrm{RCE}$

- $\mathrm{HCE} \quad=\mathrm{VA} / \mathrm{HC}$

- $\mathrm{SCE} \quad=\mathrm{SC} / \mathrm{VA}$

- $\mathrm{RCE} \quad=\mathrm{RC} / \mathrm{VA}$

Langkah ketiga: Menghitung efficiency of capital employed (CEE)

- $\mathrm{CEE} \quad=\mathrm{VA} / \mathrm{CE}$

Langkah keempat: Menghasilkan MVAIC

- $\quad \mathrm{MVAIC}=\mathrm{ICE}+\mathrm{CEE}$

- $\quad \mathrm{MVAIC}=(\mathrm{HCE}+\mathrm{SCE}+\mathrm{RCE})+\mathrm{CEE}$

Keterangan :

MVAIC: Modified VAIC

ICE : Intellectual Capital Efficiency

HCE : Human Capital Effeciency

SCE : Structural Capital Effeciency

RCE : Relational Capital Effeciency

CEE : Capital Employed Effeciency

VA : Value Added

HC : Human Capital; total beban karyawan, termasuk pelatihan

SC : Struktural Capital;VA-HC

RC : Relational Capital; biaya pemasaran

CE : Capital Employed; nilai buku dari total aset 
Proses analisis data dilakukan dengan 2 cara sebagai berikut:

1. Melakukan analisis data (content analysis). Untuk content analysis, menggunakan 4 cara sistem kode numerik (four-away numerical coding system) yang dikembangkan oleh Guthrie et al. (1999) untuk mengidentifikasi intensitas pelaporan modal intelektual dalam laporan tahunan perusahaan.

2. Terakhir melakukan analisis data dengan menggunakan metode Partial Least Square (PLS). Terdapat 2 bagian analisis yang dilakukan dalam PLS yaitu pertama menilai outer model dan Inner model sebelum menguji hipotesis.

\section{HASIL DAN PEMBAHASAN}

\section{Content Analysis}

Content analysis dalam penelitian tentang ICD telah pernah digunakan misalnya oleh Ulum (2011). Pengungkapan IC dikelompokkan dalam 3 kategori yang terdiri dari 36 item yaitu human capital terdiri dari 8 item, structural capital terdiri dari 15 item dan relational capital terdiri dari 13 item. Adapun ICD yang diungkapkan di dalam laporan tahunan perbankan sayriah pada kurun waktu 2011-2015 sebagai berikut:

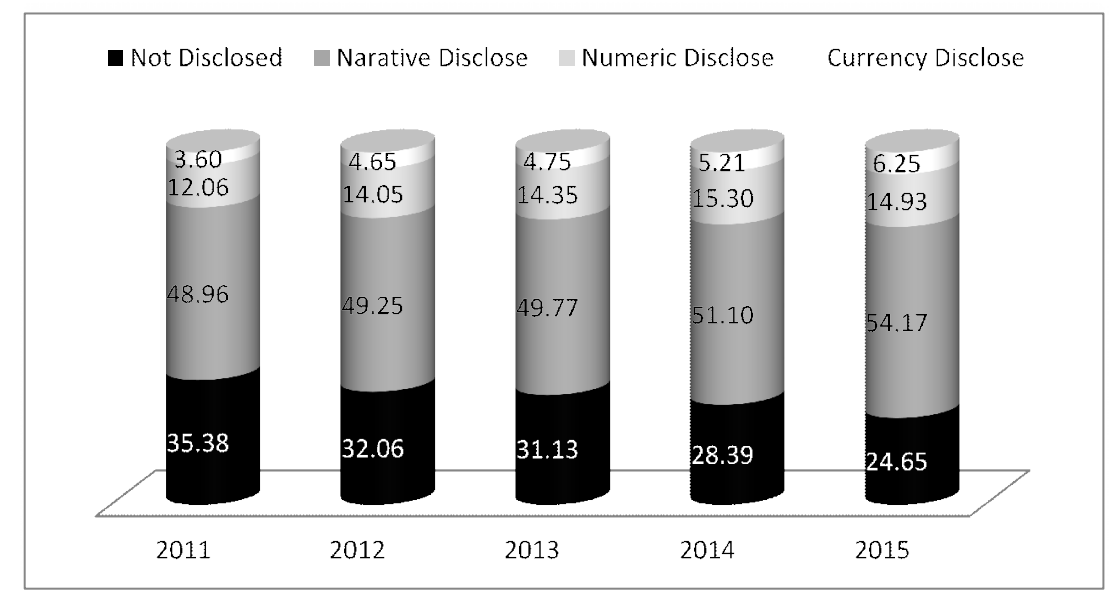

Berdasarkan gambar 1 di atas menjelaskan persentase pengungkapan IC pada laporan tahunan hasil dari grafik di atas dapat disimpulkan bahwa perbankan syariah pada tahun 2011-2015 item IC tidak diungkapkan, nilai persentase tertingi pada tahun 2011 dengan angka 35.38\%, Item diungkapkan dalam bentuk narasi persentase tertinggi pada tahun 2015 dengan angka 54,17\%, Item diungkapkan dalam bentuk numerik tertinggi pada tahun 2014 dengan angka 15,30\%, sedangkan item yang diungkapkan dalam bentuk moneter tertinggi pada tahun 2015 dengan angka $6,25 \%$.

\section{Pengujian Hipotesis dengan WarpPLS}

Untuk langkah pertama yaitu menilai outer model atau measurement model, untuk menilai outer model dapat melihat dari koefisien regresi dan signifikansi dari koefisien regresi tersebut. Hasil pengujian dpat dilihat pada gambar 3 , tabel 2 dan tabel 3 sebagai berikut: 


\section{Pengaruh \\ Intellectual \\ Capital...}

946

Gambar 3

Output WarpPLS 3.0

- Full model

Tabel 2 .

Model fit indices,

Path coefficient and

$P$ value

Tabel 3. Output Indicator Weight
Tabel 4. $R$-squared, $Q$ squared and Full collinearity VIF

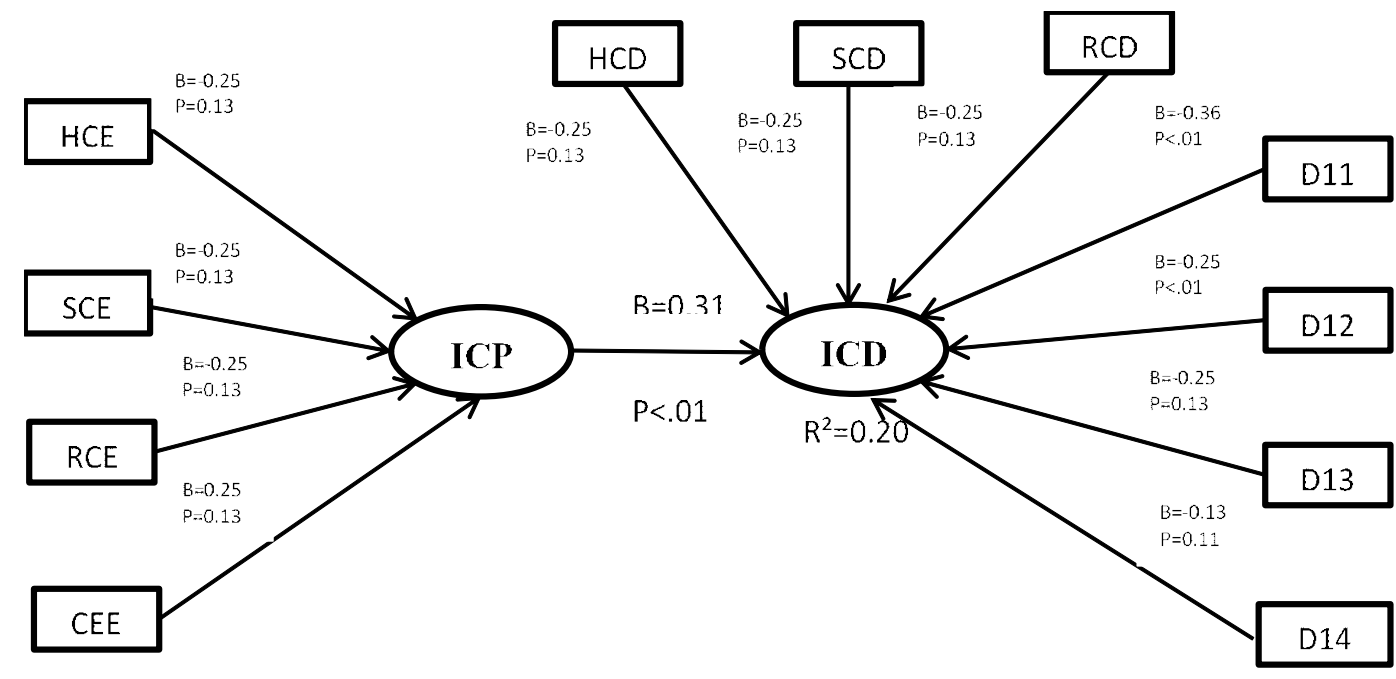

Keterangan $: * * * p<0.001,{ }^{* *} \mathrm{p}<0.05,{ }^{*} \mathrm{p}<0.10$

\begin{tabular}{llll}
\hline Model fit indices and $P$ values & APC $=0.261$ & \multicolumn{2}{l}{$\mathrm{P}<0.001$} \\
& ARS $=0.199$ & $\mathrm{P}=0.011$ & \\
& AVIF $=1.483$ & Good if $<5$. \\
Path coefficients and $P$ value & ICP-ICD & 0.314 & $\mathrm{P}<0.001$ \\
& D11-ICD & -0.36 & $\mathrm{P}<0.001$ \\
& D12-ICD & -0.25 & $\mathrm{P}<0.001$ \\
& D13-ICD & -0.25 & $\mathrm{P}=0.02$ \\
& D14-ICD & -0.13 & $\mathrm{P}=0.11$ \\
\hline
\end{tabular}

\begin{tabular}{cccccc}
\hline & ICP & ICD & SE & P Value & VIF \\
\hline HCE & $(0.434)$ & 0.000 & 0.068 & $<0.001$ & 11.741 \\
SCE & $(0.443)$ & 0.000 & 0.064 & $<0.001$ & 12.341 \\
RCE & $(-0.136)$ & 0.000 & 0.085 & 0.023 & 1.029 \\
CEE & $(0.241)$ & 0.000 & 0.094 & $<0.001$ & 1.195 \\
HCD & 0.000 & $(0.366)$ & 0.064 & $<0.001$ & 1.321 \\
SCD & 0.000 & $(0.426)$ & 0.044 & $<0.001$ & 1.854 \\
RCD & 0.000 & $(0.420)$ & 0.069 & $<0.001$ & 1.792 \\
\hline
\end{tabular}

Selanjutnya untuk langkah kedua yaitu menilai inner model atau structural model dimana penilaian ini juga diperlukan sebelum pengujian hipotesis. Penilaian inner model atau structural model dapat melihat nilai Output laten vari ${ }^{-}$ able coefficients yaitu didalamnya menyajikan nilai $R$-Square, $Q$-Square dan Full ollinearity VIF. Output laten variable coefficients merupakan salah satu yang terpenting karena menyajikan berbagai hasil estimasi yang wajib dilaporkan dalam suatu penelitian.

\begin{tabular}{lll}
\hline $\boldsymbol{R}$-squared & Q-squared & Full collinearity VIF \\
\hline $\mathrm{ICD}=0.199$ & $\mathrm{ICD}=0,202$ & $\mathrm{ICD}=1.141$ \\
& & $\mathrm{ICP}=1.049$ \\
\hline
\end{tabular}

Untuk pengujian hipotesis dilakukan pengujian direct effect antara Intellectual Capital Performance (ICP) dan Intellectual Capital Disclosure (ICD). Hasil pengujian direct effect dapat dilihat pada tabel 5 . 


\begin{tabular}{llll}
\hline $\begin{array}{l}\text { Model fit indices } \\
\text { and } \mathrm{P} \text { value }\end{array}$ & $\begin{array}{l}\text { Path coefficients } \\
\text { and } \mathrm{P} \text { value }\end{array}$ & $\boldsymbol{R}^{\mathbf{2}}$ & Effect size \\
\hline $\mathrm{APC}=0.261, \mathrm{P}<0.001$ & $0.314, \mathrm{P}<0.001$ & 0.199 & 0.101 \\
$\mathrm{ARS}=0.199, \mathrm{P}=0.011$ & & & \\
$\mathrm{AVIF}=1.483$, Good if $<5$ & & & \\
\hline
\end{tabular}

Koefisien jalur yang dihasilkan dari pengujian ini adalah sebesar 0.31 dengan nilai $\mathrm{p}<0,1$. Artinya nilai $\mathrm{p}$ dalam penelitian ini $<0.001(* * *)$. Dengan demikian dapat disimpulkan bahwa terdapat pengaruh positif dan signifikan antara intellectual capital performance terhadap Intellectual Capital Disclosoure. Artinya semakin baik intellectual capital performance maka cenderung semakin luas pelaporan modal intelektual yang dimiliki perusahaan. Dapat disimpulkan bahwa H1 diterima yaitu terdapat pengaruh positif signifikan antara intellectual capital performance terhadap intensitas pelaporan modal intelektual.

Hasil content analysis membuktikan bahwa seberapa besar perbankan syariah mengungkapkan modal intelektual yang dimilikinya. Hasil persentase ICD dapat dilihat pada gambar 2 yang menunjukkan informasi pengungkapan IC secara keseluruhan, informasi IC yang diungkapkan dalam bentuk narasi tertinggi berdasarkan jenis pengungkapannya yaitu berada pada kisaran $48.96 \%$ hingga $54.71 \%$. Angka ini berada diatas persentase seharusnya, yaitu $36.11 \%$, sementara informasi IC yang diungkapkan dalam bentuk numerik ada pada kisaran $12.06 \%$ hingga $14.93 \%$ dari seharusnya yang mencapai 50\%, sedangkan informasi IC disajikan dalam bentuk currency berada cukup jauh dari yang seharusnya (13.89 \%) yakni diantara $3.60 \%$ sampai $6.25 \%$. (Ulum, 2015c)

Sedangkan untuk persentase item yang tidak diungkapkan oleh perbankan syariah setiap tahun nya menurun pada kurun waktu 2011-2015. Pada gambar 1.2 menunjukkan turunnya persentase item yang tidak diungkapkan yaitu sebesar $35.38 \%$ di tahun 2011 menjadi $24.65 \%$ ditahun 2015 . Hal ini menunjukkan bahwa perbankan syariah memiliki kesadaran akan pentingnya mengungkapkan modal intelektual yang dimilikinya semakin terlihat. Artinya manajer meyakini bahwa semakin banyak informasi IC yang mereka ungkapkan di laporan tahunan perusahaan maka akan berpengaruh positif terhadap perusahaan atau dapat meningkatkan nilai perusahaan.

Hasil hipotesis menyatakan bahwa Intellectual Capital performance (ICP) berpengaruh positif signifikan terhadap intensitas pelaporan modal intelektual (ICD). Hasil pengujian WarpPLS menunjukkan bahwa nilai koefisien jalur sebesar 0,31 dengan nilai $\mathrm{p}<0,1(* * * \mathrm{p}<0.001)$ hasil tersebut membuktikan bahwa ICP berpengaruh positif signifikan terhadap ICD.

Intellectual Capital performance (ICP) merupakan variabel laten yang memiliki 4 indikator yang mempengaruhinya yang meliputi human capital efficiency (HCE), structural capital efficiency (SCE), relational capital efficiency (RCE) dan capital employed efficiency (CEE). Hasil untuk output indikator weight dapat dilihat pada tabel 1.2 yang menunjukkan bahwa untuk indikator HCE berpengaruh positif signifikan dengan koefisien 0.434 dan $\mathrm{p}<0.001(* * *)$ terhadap ICD, selanjutnya untuk indikator SCE berpengaruh positif signifikan dengan koefisien 0.443 dan $\mathrm{p}<0.001(* * *)$ terhadap ICD, kemudian untuk indikator RCE berpengaruh negatif signifikan dengan koefisien -0.136 dan $\mathrm{p}=0.023(* *)$, terhadap ICD, sedangkan untuk indikator CEE berpengaruh positif yang signifikan dengan koefisien $\mathrm{p}<0.001$ terhadap ICD.

Hasil penelitian ini tidak sejalan dengan penelitian yang dilakukan oleh sejumlah peneliti terdahulu (lihat misalnya: Williams, 2001; Ulum, 2012; Cahya, 2013; Ulum, 2015c) yang menyatakan bahwa ICP berpengaruh negatif terhadap ICD. Akan tetapi hasil penelitian ini konsisten, searah dan mendukung persfektif teori RBT maupun teori stakeholder. Teori RBT maupun teori stakeholder yang menjelaskan bahwa seberapa penting pelaporan modal intelektual didalam laporan

Output WarpPLS Direct Effect 


\section{Pengaruh Intellectual Capital...}

keuangan perusahaan. Menurut teori stakeholder, manajemen organisasi diharapkan untuk memberikan informasi mengenai aktivitas-aktivitas yang dilakukannya kepada stakeholder. Sementara dalam perspektif RBT, IC adalah sumber daya yang dapat membantu perusahaan mencapai keunggulan bersaing,

Sehingga dapat diasumsikan bahwa perusahaan mengelola sumber daya yang dimilikinya dengan baik akan menghasilkan kinerja IC yang tinggi, oleh sebab itu mendorong manajer untuk mengungkapkan hal tersebut sehingga jumlah pengungkapan informasi IC dalam laporan tahunan menjadi lebih luas (arah hubungannya positif). Hubungan positif yang dihasilkan dalam penelitian ini dapat mendukung sugesti bahwa perusahaan akan cenderung memperluas pelaporan pengungkapan IC didalam laporan tahunan perusahaan karena perusahaan memiliki IC yang tinggi yang dapat menjadikan perusahaan memiliki keunggulan bersaing.

\section{SIMPULAN}

Kesadaran perusahaan terhadap pengungkapan modal intelektual yang dimilikinya tergolong tinggi, dimana setiap perbankan banyak yang mengungkapkan item pengungkapan Intellectual Capital (IC) dalam laporan tahunan perbankan syariah. Hal tersebut dibuktikan dengan semakin menurun nya item ICD yang tidak diungkapkan di laporan tahunan perbankan syariah.

Hasil penelitian ini membuktikan bahwa Intellectual Capital Performance (ICP) berpengaruh positif terhadap intensitas pelaporan modal intellectual (ICD). Hal ini dapat dibuktikan dengan hasil pengukuran dengan menggunakan MVAIC berpengaruh positif signifikan $(* * * p<0.001)$ terhadap luas pelaporan modal intelektual (ICD). Artinya perbankan syariah mampu mengelola kinerja IC dengan baik yang dapat mendorong perusahaan untuk memperluas pelaporan modal intelektual yang dimilikinya.

Keterbatasan dalam penelitian ini yaitu pada analisis isi (content analysis), sebagaimana lazimnya penelitian dengan menggunakan analisis isi (content analysis), subjektifitas peneliti dalam melakukan checklist skor atas laporan tahunan perusahaan untuk mengidentifikasi informasi IC yang diungkapkan menjadi tidak terelakkan. Sehingga untuk mengurangi 'kelemahan' ini, peneliti dapat melibatkan tim penelitian yang lebih dari dua orang untuk melakukan checklist skor sehingga dapat dilakukan konfirmasi hasil secara lebih maksimal.

\section{DAFTAR PUSTAKA}

Cahya, H. M. P. 2013. "Determinan Luas Pengungkapan Modal Intellectual Pada Perbankan". Accounting Analysis Journal, Vol. 3, No. 1, hlm: 471-479.

Guthrie, J., dan R. Petty. 2000. "Intellectual capital: Australian annual reporting practices “. Journal of Intellectual Capital, Vol. 1, No. 3, hlm: 1469-1930.

Guthrie, J., R. Petty, F. Ferrier, dan R. Wells. Year. "There is no accounting for intellectual capital in Australia: A review of annual reporting practices and the internal measurement of intangibles". Artikel dipresentasikan pada $O E C D$ Symposium on Measuring and Reporting of Intellectual Capital, di Amsterdam.

Healy, P. M., dan K. G. Palepu. 2001. "Information asymmetry, corporate disclosure, and the capital markets: A review of the empirical disclosure literature". Journal of accounting and economics, Vol. 31, No. 1, hlm: 405-440.

Ulum, I. 2011. "Analisis Praktek Pengungkapan Informasi Intellectual Capital dalam Laporan Tahunan Perusahaan Telekomunikasi di Indonesia”. Jurnal Reviu Akuntansi dan Keuangan (JRAK), Vol. 1, No. 1, hlm: 49-56. 

numerical coding system". Jurnal Akuntansi \& Auditing Indonesia, Vol. 19, No. 1, hlm: 39-50.

-_- 2015b. Intellectual Capital: Model Pengukuran, Framework Pengungkapan, dan Kinerja Organisasi. Malang: UMM Press.

- 2015c. "Peran Pengungkapan Modal Intelektual dan Profitabilitas dalam Hubungan antara Kinerja Modal Intelektual dan Kapitalisasi Pasar". Artikel dipresentasikan pada Simposium Nasional Akuntansi XIIIV, di Universitas Sumatera Utara, Medan.

Ulum, I., I. Ghozali, dan A. Purwanto. 2014. "Intellectual Capital Performance of Indonesian Banking Sector: A Modified VAIC (M-VAIC) Perspective ". Asian Journal of Finance \& Accounting, Vol. 6, No. 2, hlm: 103-123.

Ulum, I., dan A. Juanda. 2016. Metodologi Penelitian Akuntansi. Yogyakarta: Aditya Media Publishing.

Ulum, I., E. Suprapti, dan Ariestyowati. 2012. "Pengaruh karakteristik perusahaan terhadap praktik pengungkapan intellectual capital dalam laporan tahunan perusahaan publik di Indonesia". Jurnal Profita, Komunikasi Ilmiah Akuntansi dan Perpajakan, Vol. V, No. Agustus, hlm: 10-16.

Wardani, R. P. 2012. "Faktor-Faktor yang Mempengaruhi Luas Pengungkapan Sukarela “. Jurnal Akuntansi dan Keuangan, Vol. 14, No. 1, hlm: 1- 15.

Wernerfelt, B. 1984. "A Resource-Based View of the Firm". Strategic Management Journal, Vol. Vol. 5, No. 2. (Apr. - Jun., 1984), pp. 171-180, No., hlm.

Williams, S. M. 2001. "Is intellectual capital performance and disclosure practices related?". Journal of Intellectual Capital, Vol. 2, No., hlm: 192-203. 
